\title{
Social Inequalities in a Time of Economic Crisis in Greece
}

\author{
Souzanna-Maria Nikolaou \\ Department of Primary Education, University of Ioannina \\ Ioannina, Greece \\ E-mail: snikola@cc.uoi.gr \\ Monika Papa (Corresponding author) \\ Athens School of Fine Arts, Greece \\ E-mail: monikapapa@gmail.com
}

Lela Gogou

Department of Education Sciences in Early Childhood, Democritus University of Thrace

Komotini, Greece

E-mail: lgogou@psed.duth.gr

Received: December 8, 2017 Accepted: December 29, 2017 Published: March 29, 2018

doi:10.5296/ijssr.v6i1.12168 URL: http://dx.doi.org/10.5296/ijssr.v6i1.12168

\begin{abstract}
The study maintains the focus at the economic crisis in Greece, in real social terms. The research highlights the evidence between the level of education and poverty, and the impact that children of poor families are facing. The authors are focusing on the lack of social protection in single parent families, as well as the significant increase in the number of unemployed in Greece during the period of the memorandum. Moreover, the lack of an effective social state and the collapse of informal support networks increases the chances of tearing the social fabric and more families going into poverty. The study also underlines the social consequences of the economic crisis that are geared towards issues of social inclusion in societies organized in relation to values and the development of skills logic, and the inability to secure full-time jobs. The absence of social protection factors, coupled with the impact of vulnerability and risk factors, are causing poverty, unemployment, loss of rights
\end{abstract}


and social support, social exclusion, discrimination, deinstitutionality, migration combined with effects on personality, developmental experiences, health of the body and soul. In Greek society, at the time of the economic crisis, there is a lack of a social protection network, and the weakening of the institution of the family. In Greece, it is necessary to approach the "new poor" in terms of politics and economy, so that they can be considered as indispensable social partners of democracy. Unprivileged social groups have to claim their rights, become part of their liberation process, and become faces of a change of personnel and social level with the ultimate goal of social transformation.

Keywords: social inequalities, economic crisis, child poverty, educational inequalities, social exclusion

\section{Introduction}

Social inequalities, poverty and social exclusion are related to the weakening of the social protection system, the inefficient social policies, and of course the lowering of public spending. Social inequalities are amongst the greatest sources of imbalance during our time, and most European Union countries face problems of poverty and social exclusion. Poverty is currently found in the most dynamic metropolis of European societies and is related to the development of social inequalities and a continuously spreading mass of unemployment. The dramatic situation of the populations living below the poverty line is noted, while the majority of the poorest nations are changed to rich countries. There is no distinction between mechanisms of regulation at an international level which would allow this social issue to be resolved or improved, in other words, to provide an effective response to this social problem. Furthermore, the living conditions of socially disadvantaged groups are not improved, since the various policies in terms of social policy prove to be ineffective due to the deterioration of living standards. In some cases, each country focuses on managing its own poverty, while a feeling that immigrants are to return to their country is rising, which sometimes directs the expulsion of illegal immigrants, many of whom are trapped in long-term personal degradation and suffering.

Most non-privileged social groups (Note 1) reside in also unprivileged urban areas where the most serious problems of degradation and social exclusion are observed. These populations have a significant unemployment rate, a very weak school level and a significant level of child poverty. The study of degraded areas of city centers highlights the complex interaction of economic, social and environmental factors contributing to the escalation of poverty and social exclusion. (Paugam, 1991; Schnapper, 1981; Guillou \& Moreau de Bellaing, 1999; National Center of Social Studies, Proceedings 2005; Paugam, 1996: 389-404; Procacci, 1996: 405-416; Gogou, 2010).

Poverty is not limited to a financial condition, that is to say an inadequate income, but it is a multidimensional reality, a multifaceted combination of deprivations, potential and needs that are not met, and also lack of participation in social affairs (Alcock, 1997: 85). Various studies and researches (Sen, 1999; Hagenaars, 1986; Ringen, 1995; Narayan et al., 2009) highlight that poverty is characterized by lack of material resources, illiteracy and social exclusion. Poverty maintains an individual in the state of moral and material dependence, which inhibits 
his autonomy and thus the groups living in poverty remain excluded from social practices. However, it remains difficult to clarify the excluded population groups (unemployed, immigrants, marginalized young people) recorded in the official statistics at national and European level. Eurostat has developed the indicator of material deprivation in the population experiencing financial difficulties in physical deprivation dimensions that characterize the dimension of economic deprivation (eg, failure to pay fixed bills, heating, emergency, etc.) and deprivation basic consumer goods (food, car, telephone, etc.). It measures access to basic species in the same way in EU countries according to the level of development of each country (Balourdos, 2012: 21-53; Council of European Union, Social Protection Committee, 2012).

In modern societies, the surveys in recent decades have been directed at populations in a state of uncertainty that were likely, to become aware or already be aware of a process capable of leading them eventually to extreme and absolute poverty, with a main but not exclusive mechanism for provoking a personal path to poverty, and long-term unemployment. The surveys were mainly focused on the disadvantaged social groups of the population and the attention of the researchers was drawn on the relationship between unemployment and employment and poverty (depending on whether the head of the household is working) and the consequences of unemployment on other members of the family (Ketsetopoulou, 2005: 59-67; Coutrot \& Dubar 1992; Gorz, 1997, et al.). In this period of economic crisis we are experiencing a new social situation that is not necessarily associated with particular social strata and there is a difficulty in determining the extent of the decline in the standard of living of the economically weak (Mouzelis, 2014).

\section{The Economic Crisis in Real Social Terms}

In Greece, even before the Memorandum period, the poverty rate was above $20 \%$, and the relationship between poverty and the level of education of the household manager was highlighted. The research data indicate the relationship between education and poverty, revealing that children of poor families with a lower educational level are at high risk of early school dropout. The educational level is related to the quality of employment, unemployment and the lack of knowledge regarding new technologies (Sakellis, 2005: 25-26). The continuity of this situation hinders the prospect of tackling the problem of poverty and social exclusion.

Moreover, socially defined educational inequalities contribute to the exclusion of individuals from the fundamental right of education and education (Chrysakis \& Balourdos, 2005: 69). The abandonment of compulsory ten-year education is an important factor in excluding people from both the labor market and the opportunities for vocational training and lifelong learning. In this way, a high risk of poverty occurs for both men $(30.45 \%)$ and women $(30.32 \%)$, while the lack of the educational asset results in social exclusion (Chrysakis \& Balourdos, 2005: 78).

In Greece, since 2003, as shown from researches, poverty is higher for the unemployed and twice as much for other population groups. Percentages of $31.42 \%$ of the unemployed, $26.51 \%$ of the pensioners and $24.97 \%$ of the inactive population are recorded as poor 
compared to only $14.2 \%$ of the employed (Ketsetzopoulou, 2005: 66). "Age" appears to be the determinant factor rather than the gender factor concerning the impact of poverty, since both the employed and the unemployed over 55 are more at risk of falling into poverty. Education is a most important factor regarding poverty, since workers with a low educational level are at greater risk of poverty than those with a high educational level (Ketsetzopoulou, 2005: 66).

Regarding the poverty level of single parent households, prior to the Memorandum, it is found that one out of three single parent families with more than one child is considered poor, since the single parent is the only one who contributes. In Greece, according to the results of the EU SILK 2003 survey, the level of economic poverty of single parent families is $28.8 \%$, while the single parent is working. High levels of poverty are found in single-parent households, while the parent in charge is a 35 to 45 year-old person, in relation to a two adult household with dependent children. Even if the single parent works, one in three single parent families with one child is considered poor. There is a lack of social protection in single parent families, while the focus is on families with many children. From a comparative study of family protection policies applied in EU countries, it is noted that in Greece there is a lack of social policies for single parent families (Kikilias, Papaliou \& Fagadaki, 2007: 124). In the overwhelming majority, single-parent households (90\%) are women in all EU countries: Ireland (99\%), Germany (96\%), Austria (95\% 26\% of single parent households are men. These findings are related to positions in the labor market, as well as to state welfare (Mouriki, 2005: 235). In Greece, single-parent families face many institutional and social problems, which are related to an assumption that the only legal form of family is that of the two spouses (Mouriki, 2005: 237).

Greek households, prior to the memorandum, were financed through bank lending with significant interest rate cuts after the introduction of the euro, aiming to increase their incomes for a better living standard. The financial crisis has overturned this situation by exposing many families to material deprivation and exclusion (Mitrakos \& Tsakloglou, 2012: 23-24). The study entitled "Social Political and Social Cohesion in Greece under Economic Crisis" (June 2012) examines the quantitative dimensions, structure and change over time of economic inequalities and poverty in the period of political transition in Greece. The analytical data from available household income and expenditure surveys have been used, as well as the primary analytical material of all available Family Budget Surveys of the total population of the country during the 1974, 1981/82, 1987/88, 1993/94, 1998/99, 2004/05 and 2008 (2008 survey conducted by the Greek Statistical Authority) (Mitrakos \& Tsakloglou, 2012: 24-25). The Family Budget Surveys used in this study refer to all areas of the country in a sample of approximately 750,000 households in 1974 and to a sample of approximately 6,000 to 6,800 households for each of the next five Family Budget Surveys (1981/82, 1987/88, 1993/94,1998/99 and 2004/05). Data from these surveys show consumer spending, income, home comforts, durable consumer goods, and the socio-economic characteristics of households and members.

In order to investigate inequality and poverty, allocations of current consumption expenditure, on household disposable income, and imputed consumption expenditure (which are added to 
the income definition in relation to imputed income) are used. In this way, Family Budget Surveys are an important source of research concerning inequality and poverty. Research data over the period 1974-2008 show that both economic inequality and relative poverty have declined significantly during the period under review, while this decline was not continuous (Mitrakos \& Tsakkloglou, 2102: 24-25). In spite of the decline recorded, inequality and relative poverty are still higher than most European Union countries (OECD, 2011, European Commission, 2011), although Greece is one of the few OECD countries for Economic Cooperation and Development, where inequality and poverty have declined over the past decades (Mitrakos \& Tsakloglou 2012: 59). Research data show that inequalities in Greece are mainly driven by differences within the various socio-economic groups rather than among them, while educational inequalities are directly related to economic inequalities (Mitrakos \& Tsakloglou, 2012: 56). Mitrakos \& Tsakloglou's analysis, highlights that Family Budget Surveys focus on private households and exclude certain poor parts of the population, such as homeless people and others, while the group of economic migrants which has considerably increased the two last decades is under-represented. In this way, the under-representation of immigrants in the sample of Family Budget Surveys demonstrates that inequality and poverty are below the real numbers while in the same time the welfare levels present to be higher than the true percentages. (Mitrakos \& Tsakloglou, 2012: 57). This study shows that indirect taxation has increased during the period under review and it is possible to overestimate the actual improvement over time of population welfare with regard to the effects of consumption distributions (Mitrakos \& Tsakloglou, 2012: 58).

Since the autumn of 2009, Greece is facing financing problems concerning the Public Sector of economy. It should be noted that in May 2010 Greece entered into a loan agreement with the European Commission, the European Central Bank and the International Monetary Fund, introducing reforms in the public and private sectors of the economy (Dafermos \& Papatheodorou, 2012: 89-90). From 2009 and onwards, the Greek economy faces double unemployment rates and a major decrease of earnings of employees both in the private and public sectors, while there is a recorded weakening of collective labor agreements and the strengthening of part-time employment, as well as the reduction of public expenditure on social protection. The Greek economy has been facing serious problems in recent years and the country's Gross National Product (GNP) does not seem to be able to return to its pre-crisis levels, at least until 2015. There has been a significant reduction in social transfers since 2010, and these figures combined with an ineffective social protection system, are an important indication that the relative poverty and living standards of the population in Greece have been dramatically affected by the crisis. (Dafermos \& Papatheodorou, 2012: 112-113).

The significant increase in the number of unemployed in Greece during the period of the memorandum has affected the social fabric, as the percentage of the unemployed who declared "household managers" have been significantly increased. The factors contributing to the so-called worker poverty vary widely between the countries of the European Union. Determining factors appear to be the low educational level, the temporary or flexible form of work, such as part-time work, etc. Low earnings combined with under-employment, particularly for certain types of family structure (single parent families), can explain the 
dimensions of poverty for some workers (Zografaki \& Mitrakos, 2012, 2012: 173-174). The existence of employment alleviates the level of social poverty, but it can lead to a significant number of low-paid workers, who are vulnerable to labor poverty (Guillaume, 2008; Hallerod \& Larsson, 2010; European Commission, 2011 in Zografakis \& Mitrakos, 2012: 174).

In the recent financial crisis in Greece (MEMORANDUM) there is a number of young people who are not only confined to population groups that are particularly vulnerable due to lack of assets, limited reactivity and reduced access to services and products, but also includes new groups who without this economic crisis would not have been affected. The economic crisis mainly affects the working population with consequences in terms of rising unemployment and wage cuts. The economic crisis and the restructuring of the labor market, structural changes in employment, uncertainty and poor quality jobs in the secondary labor market (low-paid jobs) create a new group that cannot be absorbed and fully integrated into the labor market. Also, another group greatly affected by the crisis is families with one worker, especially in the context of rising unemployment or low-paid work where many families can no longer be maintained and meet basic needs. The lack of an effective social state and the collapse of informal support networks increase the chances of the family with one worker going into poverty.

The elderly and the children are another group that raises concerns. The elderly who are alone in the world, are challenged daily by their lack of income and their psychosomatic deprivation due to chronic hardships. Income poverty also affects children with an impact on their physical and psycho-intellectual development. The long-term unemployed or poor parents, or even low-paid or unstable employment, are cases investigated by the study regarding the deprivation (material, cultural, cultural, etc.) that children are subject to as well as their psycho-emotional and educational development with the adult model that may affect the child in its choices in education and the future labor market. And all these conditions form the background to never escape the vicious circle of poverty as they become the next generation of unemployed poor. Along with children, young people are also entering the labor market, who, in the absence of jobs, either occasionally work in low-paid jobs or are exposed to unemployment or migrate to other European countries to find a job, since youth unemployment in Greece high and worrying levels. Under these circumstances, the young poor along with the populations that represent the "traditional poverty" also cause an increase in the frequency of the poor in Greece (Balourdos, 2012: 29-31).

In Greece, the Memorandum period exacerbated the living conditions of children, according to the research findings of the study on child poverty, prepared on behalf of the Greek National Committee for UNICEF (UNICEF Greek National Committee [Abstract] 2017). This report exploited the most recent empirical data derived from surveys conducted both by the Hellenic Statistical Service and EUROSTAT. It illustrates the level of living and welfare of children in Greece through alternative indicators measuring poverty, material deprivation and social exclusion. Child poverty has a negative impact on the future of children -as future adults, and consequently contributes to the reproduction of inequalities and poverty, which has a dramatic impact on the country's economic situation. The prolonged economic downturn and austerity policies in Greece through the Memorandum period, have had a major 
impact on children, who face very high risk of poverty and material deprivation. This Report highlights the level of living of children in Greece through indicators for measuring poverty and social exclusion, as well as through the research data of the Greek Statistical Office of EUROSTAT.

The phenomenon of child poverty entraps the individuals at a sensitive age, thus contributing to the reproduction of educational and social inequalities. Since 2009, family income in Greece has undergone a significant decline. Families are therefore unable to respond to basic needs, mostly related to their standard of living. It appears that Greece is among the 14 oldest countries of the European Union, where children experience severe material deprivation. This data reveals the conditions in which a large part of families with children lives in Greece, as well as the decrease on policies and spending for social welfare on this issue, which is vital. In times of economic crisis, the living standards of families with children have had a greater negative impact than the rest of the population in Greece. Child poverty has a negative impact on a children's future and, consequently, on the economy of the country. Children in Greece during the Memorandum period are at a higher risk than adults. According to this report, the risk of relative poverty of children from $23 \%$ in 2009 is $28.8 \%$ in 2012 and decreases to $26.6 \%$ in 2014. This report shows that some 500,000 children in Greece live in poor families, due to the Memorandum. The 2015 research data, according to the UNICEF Report, show that 1 in 2 children live in conditions of material poverty.

The risk of poverty and social exclusion is much higher for children living in Greece than the corresponding average of all 27 European Union countries, since the austerity policies implemented in Greece, through the Memorandum period, contributed to the increase of child poverty.

\section{Social Consequences of the Economic Crisis and Challenges}

The social consequences of the economic crisis are oriented towards issues of social inclusion in societies organized in relation to values and the development of skills logic. It is highlighted that the inability to secure full-time jobs, keeps a person in a state of moral and physical dependence, which intercepts any autonomy, while it is difficult to clarify the excluded population groups (unemployed, immigrants, marginalized youth), since they are recorded less and less in the official statistics (Paugam, 1991, 1996).

In Greece, through the Memorandum period and due to the severe economic crisis, there was an unexpected exclusion from the protection of the social security system, regarding social groups who were "close to poverty", which led them to actual poverty. Moreover the restructuring of the market labor, is associated with other problems such as family crisis (Note 2), failure to repay mortgage loans, overcharging and inability to maintain support from social service networks. The economic crisis affects the income, reduces the demand for work and leads to an increase in unemployment and a reduction in wages. The austerity measures that governments had to implement in order to reduce any government expenditure and therefore reduce the government budget, decreased the income of the state's employers, as well as pensions or other social benefits. The economic crisis affects the purchasing power of households, as the reduction in income is overwhelming those families who have 
accumulated debts (housing or consumer loans). The reduction in income and the depreciation of the value of assets causes financial constraints and material deprivation, while the prices are increasing and thus reinforcing the general insecurity. The economic crisis Greece is facing since 2009 strengthens the demand for social protection while the government's social spending is decreasing. It is considered necessary to create a viable and effective social safety net so that the Greek society can overcome the crisis with as little impact as possible (Matsagani \& Leventi, 2012: 65-87).

Social exclusion and social degradation are manifested in Greece during the economic downturn in a variety of ways. The rise in social degradation cannot be explained solely by the increase of poverty resulting from the lack of money income or the lack of work even if it appears to be the predominant cause. Research is no longer recording employment as an effective anti-poverty net, since the poverty of working poor is high (for Greece in 2010 at $13.8 \%$ ). "One in two young people is unemployed or even poor, while the children of the economic crisis are "the generation growing in poverty" (Balourdos, 2012: 48). Poverty is no longer determined only by the household income but it is necessary to consider whether a person has the opportunity to live with dignity (heating, staying in a "habitable" home, holiday once a year, using technology etc.) to participate in social activities, to enjoy a satisfactory standard of living (Townsend, 1979). Therefore, extreme poverty cannot be countered in those countries where the Minimum Guaranteed Income policy has not been implemented by an active welfare state that will ensure (with income support and access to services) a decent living for those who are unable to work (Balourdos, 2012: 49).

The absence of social protection factors, along with the impact of vulnerability and risk factors, are causing poverty, unemployment, loss of rights and social support, social exclusion, discrimination, deinstitutionalization, migration combined with effects on personality, developmental experiences, health of the body and soul. For example, people living in extreme poverty and ending up -in the worst case- in being homeless, face the lack of a support network (Thedorikakou et al., 2012, 2013; Alamanou et al., 2011), they are experiencing impairment of functionality and reduced social skills, extreme social stigma, and psychiatric illnesses (Martens, 2001), attempt suicide and drug use (KYADA, 2013), are often victims of abuse (Goodman et al., 1995; Theodorikakou et al., 2012), while the lack of housing drastically reduces the prospect of employment. As stressed in the surveys, the effects of extreme poverty are also devastating for children in terms of their cognitive, kinetic and mental development, the increase in their neglect and abuse, their exposure to mental trauma, or being taking care by social Institutions (Asimopoulos, 2016).

Poverty and social exclusion are related to social cohesion. The steady rise in unemployment has been linked to the crisis of the social bond since the late 1970s and has had an impact on a significant part of the active population in terms of social exclusion. Considering that full employment is becoming progressively an inaccessible ideal, we are wondering about the role of employment in the structure of the social body. The economic crisis is interpreted as the end of the model for the development and management of social relations and marks the entry of a waged-earning society into crisis. Indeed, full employment is nowadays an impersonal reality and the uncertainty of personalization of occupational situations is the 
accepted reality. Employment is a dominant form of social bond, and the situations that are shaped by unemployment, such as material deprivation and psychological despair, empirically validate the importance of employment in shaping the social order, since work as a value and reality is placed at the center of human existence. Since the 19th century, employment has not been perceived as a means of increasing wealth or as a simple factor of production but also as a means of realizing the liberation of the individual, since through work the individual acquires his/her autonomy and becomes a member of society. Employment is an activity and contributes to the creative liberation of people and their mutual recognition (Arendt, 1988; Schnapper, 1981). In this sense, we believe that employment must be understood not only in the sense of an occupational activity but above all in the sense of a human activity aimed at a creative change in personal and social level.

The liberalization of trade contributes to a new international division of labor, flexible working and reduced working hours. Poor employees who feel exploited by contributing to the wealth of others claim they are not being recognized. In this sense, it seems that economic inequalities that are perceived as unfair adopt the language of recognition and contempt when the contribution of collective or personal work to the shaping of social benefits is ignored. The dominant axis is not only the redistribution of wealth but also recognition, while the claims of certain social groups or communities make it clear that individuals seek recognition (Dubet \& Martuccelli, 1996; Touraine, 2005; Honneth, 2000).

In order to improve the situation, reforms are required, at the level of the economy, enabling citizens to live well in terms of both income (wages, jobs) and education. Citizens will be able to access jobs with a decent salary that will allow families to ensure a good standard of living for their children, while parents themselves can evolve socially and creatively through work for the benefit of all. In Greek society, at the time of the economic crisis, there is a lack of a social protection network, which leads the new social strata to insecurity and the weakening of the institution of the family. The main institutions, such as the Family and the School, are in crisis and can no longer be defined as systems of mediation between the individual and society. In this way, the role of the family in terms of socialization is limited. The school has been studied as an institution of socialization, while students experience it as a mechanism of choice and orientation and less as a place where their personality is shaped. The weakening of institutions is translated by the loss of their socialization function, since they do not uphold the mediation function between the individual and society (Dubet \& Martuccelli, 1996; Touraine, 1997; Lapeyronnie, 1993). The consequences of this institutional weakening are individualism and the revival of ethnicities. Individuals rely primarily on their experience and do not associate their personality with a broader social and moral framework but are integrated according to their origin and their particular culture in communities which, unlike institutions, are not founded on the right reason but on tradition (Lapeyronnie, 1993). Today's sociological reflection, according to Alain Touraine, addresses both cultural issues and the consequences of the economic crisis on key institutions of society and their impact on everyday social interaction and social cohesion. According to Touraine, the study and interpretation of the new social reality requires a long period of analysis and reflection, pointing out that institutions are often factors of inefficiency, and solutions previously given cannot be applied to similar situations today (Touraine, 2005, 1997). 
According to this position, sociological analysis should concentrate on both socially active persons and social movements (Touraine, 1978, 1984) and on securing the fundamental rights of subjects and cultural movements (Touraine, 2005). People are thus defined by their social characteristics and social relations as well as cultural rights. The introduction of the cultural paradigm, as well as the safeguarding of human rights, takes the lead in claiming the cultural rights of defending particular characteristics (Touraine, 2005). Alain Touraine's sociological theory focuses on social action as well as on the ability to transform society through social action. For Touraine, society is understood to be the product of the social action of individuals and groups, perceiving man as a producer of his history. In the sociological thought of Alain Touraine, the subject has a dominant position and the post-industrial society is characterized by the transition of the historical subject to the acting person (Touraine, 1965, 1984). Current social conditions do not facilitate interaction between subjects. That is why the political and scientific community must focus on the subject, taking into account the personal identity and the particular culture of a subject who will be autonomous, responsible and liberated from tradition by participating in a streamlined world. Human coexistence, according to Touraine, requires not only an effort of mutual understanding but also a dialogue between the acting subjects and collectives that have different historical experiences. On the one hand, there is the question of recognizing and accepting the presence of different cultures and their ability to formulate their own reason; on the other hand, it is the question of certain communities that defend the penetration of individuals, ideas, customs at a time when globalization is not only engaged in economic terms but also in terms of cultural identity (Touraine, 1997, 2005). Social and personal degradation is connected with the circumvention of the Universal Declaration of Human Rights, since economic and social rights are being violated even in societies with the same language, the same culture and the same historical past. Also during the recession of the economic crisis, civil and political rights are being violated. Social policies must contribute to the reintegration of those excluded from work, to the establishment of the right to work and to the training of persons, at least at the level of basic knowledge and at the level of professional qualifications, thus guaranteeing the development and the dignity of all human beings in a particular place. It is necessary to promote the training of professionals and citizens for a genuine cooperation with the most disadvantaged populations.

The policy / the government must guarantee the development and dignity of all people, particularly in countries such as Greece, which have been greatly affected by the economic crisis with a direct impact on people's livelihoods (severe material deprivation and over-indebtedness, child poverty, young people unemployment). The reintegration of those who have been excluded from work, the establishment of the right to employment and the training of people, at least as far as basic knowledge is concerned, and the guarantee of minimum guaranteed income, is becoming a major priority. The degradation of the welfare model in countries of the European South and the fact that even the self-help net is perforated, requires the planning of a National Reform Plan, with persistence and determination and with specific targets for poverty reduction (Balourdos, 2012: 49). 


\section{Conclusion}

In Greece, it is necessary to approach the "new poor" in terms of politics and economy, so that they can be considered as indispensable social partners of democracy. The so-called vulnerable social groups must enjoy their rights, re-assume their responsibility and be part of their reintegration process. Special organizations and citizens should be involved in a participatory way with non-privileged people, taking into account the experience and knowledge of the subjects in order to promote appropriate measures and social policies. It is therefore necessary to devise new forms of joint representation at all levels in order to promote social programs. This will eventually help to alleviate poverty by providing state spending to address the new social problems.

The account of the past decades shows an increase in social inequalities and the socially excluded as those who are sinking into silence. Poverty is distinguished from social exclusion, as social exclusion indicates a process of rupture within the social fabric. Exclusion is a process that results from job insecurity and the fragility of the social bond, and is the result of the overall transformation of socialization, tending to social and personal degradation. The accumulation of social problems such as school failure, early school leaving, lack of education, increased unemployment of skilled and unskilled people contribute to the genesis and perpetuation of the exclusion process and it is considered that the search for the solution is based on studying the way in which the labor market evolves and, above all, the recruitment mechanisms. To remove people from stable employment, contributes not only to the deprivation of material resources but also to the absence of social relations (Dubar, 1991; Shnapper, 1994; Coutrot \& Dubar, 1992; Paugam, 1991, 1996).

Furthermore, tackling social degradation makes it necessary to transform representations of the poor that have been "created" by income poverty, deprivation and unemployment. They should be given the means to enable their involvement, in order to improve their situation and to be able to participate in social affairs. Therefore, there is a need to develop new policies who will actually take the necessary action to enrich the knowledge of individuals and moreover to address and manage their problems at an individual and collective level.

Lastly, it should be highlighted that the reduction of social inequalities must be the focus of a strategy that aims to peoples coexisting, to a humanitarian world that is necessary for the survival of all us. It is a strategy that we must capture and elaborate in cooperation with the people, for a strategy that will include a multiplicity of actions that will be carried out both locally and globally. Unprivileged social groups have to claim their rights, become part of their liberation process, and become the faces of a change on a personal and social level with the ultimate goal of social transformation.

\section{Notes}

Note 1. The reference to the concept of unfavorable social groups suggests a variety of categories that are confronted with uncertain situations and are often vulnerable (vulnerable). These social categories are defined by demographic criteria (age for school-aged children, adolescents, young adults, elderly people), school criteria (absence of schooling, early school 
dropout) and socio-economic criteria (exclusion from the labor market or integration, which, in terms of social status, income or working conditions, becomes uncertain).

Note 2. For the family welfare in the case of Greece, see Th. Papadopoulos \& A. Roubakis (2014), The Family Welfare Capitalism in Greece: Crisis of Social Reproduction and Anti-Social Policy, in S. Zarampaloukou \& M. Koussi (eds.), Social aspects of the crisis in Greece, Athens: Pedion, pp. 273-304, n. 282:"... the family has traditionally been an important part of the corporate and customer system, creating and maintaining networks of political, social and professional contacts within and outside the state and the market. [...] enforced social rights and could, through its members who participated in permanent jobs (eg the State), provide financial support but also access to health services and allowances (medical coverage of children, etc.) ".

\section{References}

Alamanou, A., Stamatogiannopoulou, E., Theodorikakou, O., \& Katsadoros, K. (2011, September). "The Configuration of Homelessness in Greece during the financial crisis", In European Research Conference, Homelessness, Migration and Demographic Change in Europe, Pisa, 16th September.

Alcock, P. (1997). Understanding Poverty. 2end ed. Basingstoke, Palgrave Macmillan, https://doi.org/10.1007/978-1-349-25666-2

Arendt H. (1988). La Condition de L'Homme Moderne, Paris, Pocket.

Asimopoulos, Ch. (2016) The psychosocial profile of the homeless, Announcement in: Scientific Seminar "Strategy for the fight against homelessness and social housing in times of recession", 24/2/2016, Athens: EKKE / Technological Educational Institute of Athens.

Athens City Home Reception Center (2016), Program GR.08.01: Combating Poverty and Social Extinction, Steetwork Group, Ch. Maltezou \& M. Vanikioti, Athens: (http://socialpolicy.gr/2016/06.html)

Balourdos, D. (2012). "Poverty in Greece: Trends, Challenges and Policies" In: New Poverty and Social Exclusion, Policies to Combat and Establish a Minimum Guaranteed Income, D. Balourdos, M. Petrakis, Athens: House of Hellenes, pp. 21-53.

Bank of Greece report (2012). Social Policy and Social Cohesion in Greece in Crisis conditions.

Bank of Greece report (2016). Governor's Report for the year 2015, Bank of Greece. [Eurosystem "Human Capital Fugitive: Modern Migration Trends in the Times of the Crisis"].

Blattier, C. \& Robon, M. (2000). La delinquance des mineurs en Europe, Grenoble, Presses Universitaires de Grenoble.

Council of Europe (1999). European Sourcebook of Crime and Criminal Justice Statistics, Strasbourg. 
Council of European Union, Social Protection Committee (2012). Third Report on the Social Impact of the Economic Crisis and Ongoing Fiscal Consolidation 2011.

Coutrot, L. \& Dubar, C. (eds) (1992). Cheminements professionnels et mobilités sociales. Paris, La Documentation Française.

Chrysakis M., Baldourd D. (2005). "Educational Dimensions of Poverty and Social Exclusion: The Two-Way of a Relationship" in Poverty, Exclusion and Social Imbalances, Conference Proceedings, Lavrio, September 22, 23, pp. 69-80.

Daffermos G. and Papatheodorou Chr. (2012). "Economic crisis in Greece and the European Union": the effects of the macroeconomic environment and social protection, in the Bank of Greece Report (2012). Social Policy and Social Cohesion in Greece in Crisis.

Dubar, C. (1991). La socialisation. Construction des identités sociales et professionelles, Paris, A. Colin.

Dubet F. and Martuccelli D. (1996). A l'école. Sociologie de l'éxpérience scolaire, Paris, Seuil.

Gogou L. (2010). Understanding social phenomena and perspectives of social research, Athens: Grigoris.

Grenier, P. (1996), Still dying for a home, CRISIS, London .

Goodman, L. A., Dutton, M. A., \& Harris, M. (1995). Episodically homeless women with serious mental illness: Prevalence of physical and sexual assault. In American Journal of Orthopsychiatry, 65(4), 468-478. https://doi.org/10.1037/h0079669

Gorz, A. (1997). Misères du présent, richesse du possible, Paris, Galilée.

Guillou J., Moreau de Bellaing L. (1999). Misère et pauvreté. Sans domicile fixe et sous-prolétaires, Paris, L'Harmattan.

Hagenaars, A. (1986). The perception of poverty. North Holland. Amsterdam.

Honneth A. (2000). La lutte pour la reconnaissance, Paris, Cerf.

Ketsetsopoulou, M. (2005), "Labor Market and Poverty", In: Poverty, Exclusion and Social Imbalances, Proceedings of the Conference, Lavrio, pp. 59-67.

Kikilias H., Papaliou O., \& Fagadaki E. (2007). Dimensions of social exclusion of single-parent families in Greece, Athens, EKKE (National Center for Social Research).

Lapeyronnie, D. (1993). L'individu et les minorities, Paris, PUF.

Martens, Willem HJ. Homelessness and mental disorders: a comparative review of populations in various countries. In International Journal of Mental Health 30.4 (2001): 79-96. https://doi.org/10.1080/00207411.2001.11449534

Matsanganis M., \& Leventis P. (2012). The distributive effects of the crisis on income distribution in Bank of Greece Report, Social Policy and Social Cohesion in Greece in Crisis 
Conditions pp. 65-87.

Mitrakos, Th., \& Tsakloglou P. (2012). "Inequality, Poverty and Material Welfare: From the Transition to the Current Crisis", in the Bank of Greece Report (2012). Social Policy and Social Cohesion in Greece in Crisis Treaties, pp. 25-63.

Mouzelis, N. (2014) "Developments that led to the crisis", in S. Zambarloukou \& M. Koussis (eds.) Social aspects of the crisis in Greece, Athens: field, pp. 35-43.

Mouriki A. (2005). "Civil Aspects of Poverty and Social Exclusion" in Poverty, Exclusion and Social Imbalances, Conference Proceedings, Lavrio, pp. 237-241.

Narayan, D., Pritchett, L., \& Kapoor, S. (2009). Success from the Bottom Up. Vol. 2 of Moving Out of Poverty.

National Center for Social Research (2005). Poverty, Exclusion and Social Inequalities, Conference Proceedings, Lavrio, 22, 23 September.

Papadopoulos, Th., \& Roubakis, A. (2014), The Family Welfare Capitalism in Greece: Crisis of Social Reproduction and Anti-Social Policy, in: S. Zarmaloukou \& M. Koussi (eds.). Social aspects of the crisis in Greece. Athens: field, pp. 273-304Paugam, S. (1991). La disqualification sociale, Paris, PUF.

Paugam S. (1996). « Pauvreté et exclusion. La force des contrastes nationaux », in Paugam S. (ed.). L'exclusion. L'état des savoirs, Paris La Découverte, pp. 389-404.

Procacci G. (1996). « La naissance moderne de la pauvreté », in Paugam S. (ed.). L'exclusion. L'état des savoirs, Paris La Découverte, pp. 405-416.

Ringen, S. (1995). Well-being, measurement, and preferences. In Acta Sociologica, 38(1), 3-15. https://doi.org/10.1177/000169939503800102

Sakellis G. (2005). "Social Policy in Action Against Poverty and Inequalities in Greece" in Poverty, Exclusion and Social Inequalities, Conference Proceedings, Lavrio, September 22, 23, pp. 23-27.

Schnapper, D. (1981). L'épreuve du chomage. Paris, Gallimard.

Schnapper, D. (1994). La communauté des citoyens, sur l'idée moderne de nation, Paris, Gallimard.

Sen, A. (1999). Development as Freedom. Oxford University Press.

Smith, M. P., \& Guarnizo, L. E. (eds) (1998). Transnationalism from Below, New Brunswick, N.J. Transaction Books.

Theodorikakou, O., Alamanou, A., Stamatogiannopoulou, E., Tourkou, A., Karydi, K., Sarantidis, D., \& Katsadoros, K. (2012, September). Homelessness in Greece-2012: An In-depth Research on Homelessness in the Financial Crisis. In Presentation at European Research Conference: Access to Housing for Homeless People in Europe, York (Vol. 21). 
Theodorikakou, O., Alamanou, A., \& Katsadoros, K. (2013). Neo-homelessness and the Greek Crisis. European Journal of Homelessness, 7(2), 203-210.

Townsend, P. (1979). Poverty in the United Kingdom. London. Allen Lane and Penguin Books.

Touraine, A. (1978). La voix et le regard, Paris, Seuil.

Touraine, A. (2005). Un nouveau paradigme, Paris, Fayard .

Touraine A. (1965) Sociologie de.l'action, Paris,Seuil.

Touraine A. (1984). Le retour de l'acteur, Paris, Fayard.

Touraine A. (1997). Pourrons-nous vivre ensemble ? Paris, Fayard.

UNICEF Greek National Commission (Summary) (2017). The situation of children in Greece. Children of the crisis, UNICEF / for all children. https // www.unicef.gr / uploads / filemanager / PDF / 2017 / children-in-greece-sum-pdf

Zografakis, S., \& Mitrakos, Th. (2012). The risk of low income in households of employees and unemployed during the current crisis, In: Social policy and social cohesion in Greece under the current the economic crisis, Athens: Bank of Greece (in Greek) (173-215).

\section{Copyright Disclaimer}

Copyright for this article is retained by the author(s), with first publication rights granted to the journal.

This is an open-access article distributed under the terms and conditions of the Creative Commons Attribution license (http://creativecommons.org/licenses/by/3.0/). 